\title{
Relationship between Lifelong Learning Levels and Information Literacy Skills in Teacher Candidates
}

\author{
Dilek Yalız Solmaz \\ Faculty of Sport, Anadolu University, Turkey
}

Copyright $\bigcirc 2017$ by authors, all rights reserved. Authors agree that this article remains permanently open access under the terms of the Creative Commons Attribution License 4.0 International License

\begin{abstract}
This study aims to examine the relationship between lifelong learning levels and information literacy skills in teacher candidates. The research group consists of 127 physical education and sports teacher candidates. Data were collected by means of "Lifelong Learning Scale (LLL)" and "Information Literacy Scale". In the data analysis, "mean, standard deviation and Product-Moment Correlation coefficients" were used. As a result of the study, it has been observed that participant student' LLL levels are above the average. Sub-dimensions of LLL levels have been analyzed, it shows that participant student' curiosity, perseverance, motivation and self-regulation subscale scores, were slightly above the mean score of the scale. Another result obtained from this research is that students' information literacy trends are also quite high. It shows that students' "defining information needs" "access to information" "use of information" and "ethical and legal settings in use of information" subscale average scores is the high level. According the results of the analysis, there is a significant relationship between students' information literacy skills and LLL levels. This relationship is positive and at moderate level. Thus, it is understood that when students' information literacy skills increase their attitudes toward LLL will also increase in parallel at moderate level.
\end{abstract}

Keywords Lifelong Learning, Information Literacy Skills, Teacher Candidates, Physical Education and Sport, Correlation

\section{Introduction}

The rapid changes in information and communication technologies brought an information explosion. Thus the age we are living in is called information age and societies that meet the necessities of this time are called information societies. While the information produced gave birth to new technologies, these technologies enable information to be shared faster and easier day-by-day. This cycle sets forth a level of development that puts information in its center both for individuals and societies. In an information society where change is present in every part of life, the profile of people needed changes as well. This change that is based on economic and technological innovation, necessitates qualified work force in every industry. In an environment where information is shared so fast and dense, the successful individuals of our age would be individuals who can use information hectically while deciding on how to solve a problem they interact with [1].

In the past where information could only be produced and shared on printed paper, basic skills such as reading, writing, listening and speaking were sufficient for people of those times to be information consumers. But in information societies where existing information loses its relevance quickly, a life-long success is impossible with information and skills gained in a certain period of time. In such an environment, qualified work force refers to someone who constantly improves themselves by renewing their information and skills. Thus, individuals living in information societies are in a continuous learning process that goes on through life as well as applying what they learned to their lives. The term "learning society" which is used for defining information societies is a reflection of this reality. In other words, information societies require individuals that "improve themselves" and have "life-long learning" skills [1].

In the information age, life-long learning refers to a learning process that continues through life and is everywhere in order to adapt to ever-changing conditions in contrast with education and learning skills compressed to a particular period of life. Life-long learning also means creating new opportunities for individuals by updating their basic skills or providing more advanced educational possibilities [2].

\subsection{Lifelong Learning}

Today human lifespan being longer when compared to the past; scientific, technological and cultural changes 
happening rapidly and the sustainability of the change in information leaves today's individuals in need of a continuous learning. As a result of this need, education today has gained a status that cannot be limited to particular time periods in human lifespan, and even the most developed countries have begun a quest for constantly developing the educational system and increasing the quality of education. At the end of this development and change, the concept of "lifelong learning" is introduced, which enables individuals to learn the knowledge and skills that they need at any stage of their lives [3].

The concept of lifelong learning was first employed in 1920s by John Dewey, Eduard Lindeman and Basil Yeaxle, starting out from the idea that it is a continuous part of everyday life [4]. Lifelong learning is defined by European Commission [5] as "learning activities undertaken throughout life resulting in an improvement in knowledge, skills and competences within a personal, civic, social and/or employment-related perspective". Lifelong learning term is described as the intentional learning that people engage in throughout their lives, for a personal and professional fulfilment, and to enhance the quality of their lives [6]. About the concept of lifelong learning, Reinsch [7] highlights that educational system is required to raise individuals who are undertaking lifelong learning, and besides the educational system, businesses and industry are in need of lifelong learning, and that the individuals are ought to actualize self-learning to transform the concept of life-long learning into philosophy of life

In recent years, there has been a great deal of knowledge regarding the recognition of LLL, which includes all formal, non-formal and informal aspects of education and training, at all ages and stages of life, and in all organizations. So schools, colleges, universities and other institutions of higher education are required to reconsider their facilities in the general domain of learning throughout life as a part of this recognition [8].

Lifelong learning means providing a second chance for individuals by way of developing basic skills as well as various learning opportunities [2]. The understanding of lifelong learning acknowledges that learning is not restricted to time and place and it can be undertaken anywhere that the passion for learning is present.

Lifelong learning is a skill that all individuals in the information societies are ought to have. Acquiring this skill, individuals are enabled to benefit from any kind of opportunity that they may encounter in their lives. Furthermore, lifelong learning helps to cope with changes in areas such as science and technology. And the keystone of lifelong learning is information literacy [1].

\subsection{Information Literacy}

According to American Library Association (ALA) report, information literacy is a set of abilities requiring individuals to "recognize when information is needed and have the ability to locate, evaluate, and use effectively the needed information". Information literacy also is increasingly important in the contemporary environment of rapid technological change and proliferating information resources [9]. According to Henderson and Scheffler [10], individuals with information literacy are people who know the ways to reach information and use it appropriately by interpreting the information. The need for information and the increase in the quantity and variety of information made information literacy a necessity [11]. Information literacy is the set of skills needed to discover, retrieve, analyze, and use information. The twenty-first century has been named the information era, due to the explosion of information and the information sources. Due to information explosion it has become increasingly clear that students cannot learn everything they need to know in their field of study, within a few years, at school. Information literacy competencies empower the people with the critical skills that will help them to become independent lifelong learners. These competencies will enable people to apply their knowledge from the familiar environment to the unfamiliar [12].

In a study conducted by Doyle in 1992, information literacy was taken into consideration extensively for the first time. According to Doyle [13], an individual who has information literacy;

- recognizes that accurate and complete information is the basis for intelligent decision making

- recognizes the need for information

- formulates questions based on information needs

- identifies potential sources of information

- develops successful search strategies

- accesses sources of information including computer-based and other technologies

- evaluates information

- organizes information for practical application

When the existing definitions are analyzed, it is seen that information literacy points out to many skills that can be used during the process of accessing knowledge and using information. In a period where the environment that knowledge is produced and shared diversifies and gets more complicated, the use of technology when accessing information is an indispensable factor of information literacy.

\subsection{Information Literacy and Lifelong Learning}

Information literacy and lifelong learning have a strategic and mutually strengthening relationship that is essential in the success of every individual, organization, institution and society inside the global information society. Breivik [14] notes that the skills of information literacy lay the foundations of lifelong learning in a world where information is cumulatively increasing and the technologies used to reach the mentioned information is in a constant change. Also, Breivik [14] expresses that information literacy is a device where lifelong learning is the goal. 
It is an important step in the development of lifelong learning that individuals are provided with the skills of information literacy [15]. It is the most important goal of education to raise individuals who are able to enact lifelong learning independently in today's information society. To reach this goal, the indispensible mean is information literacy. Therefore, in the course of obligatory education process it has become mandatory to educate the students to be able to reach the information that would meet their requirements in their personal, social and business lives, to evaluate this information and to use it effectively (information literate); in other words, to educate skilled individuals who are able to enact lifelong learning independently [14]. Individuals with information literacy and life-long learning skills are ready for all kinds of changes and hardship their careers and personal lives may bring [14].

Individuals in information society may come from above the struggles that they face when they internalize the principles of lifelong learning as information literacy. Individuals who have the skills of information literacy are productive individuals both in education and business environments. The most important goal of education in information society is to raise individuals who have learned how to learn as lifelong learners. To reach this goal, the indispensible mean is information literacy [16].

When studies about life-long learning in Turkey are analyzed, have been reached by the studies that determining the key skills of life-long learning for the teacher candidates and teachers [17]; examining lifelong learning trends of university students, teachers and teachers candidates [2-18-19-20]; determining teachers candidates' views about life-long learning [21-22]; examining perceptions of teacher candidates and teachers' competences for lifelong learning [23-24-25-26].

When latest researches in the literature on information literacy are analyzed, it can be seen that researches are conducted either for information literacy or for the skills a person with information literacy must possess [27-28-29-30]. In theoretical studies, the definition of information literacy stated to include detecting the need for information, formulating information searching strategies, determining its place and accessing it, analysis on information, evaluation, transferring, possessing problem solving skills, life-long learning, learning society, sustainable education, excess knowledge, increase in the amount of information and respect to copyrights [31]. When studies investigating the relationship between lifelong learning and information literacy are examined, only theoretical studies have been conducted. But no analysis work has been found.

The role of information literacy is vital for lifelong learning as it enhances the quality of education both in learning environments and in educational settings. It is in evidence that various models should be used, a number of activities should be enacted, and the efficiency of these should be investigated for the purpose of providing these skills in all the educational levels. Teachers' role is important in bringing up individuals who are life-long learners and who improve themselves constantly. In order for teachers to undertake this role, they must be individuals who learn by themselves in their educational and professional lives and thus they must be leaders on providing their students with studying opportunities, accessing information and using it [32]. In addition, Breivik [33] states that it is important to include information literacy in teacher training programs. In this context, it is regarded as an important step in the development of lifelong learning that individuals are provided with the information literacy skills [15] because it is only possible for the teaching candidates to be successful in their teaching careers depends on a learning process that will continue throughout their life [28]. For this reason the pre-service training for teachers must also be suitable for gaining the mentioned qualities.

Despite conceptual research on the relationship between lifelong-learning and information literacy, no analysis work has been found. It would be useful to determine the relation between their tendency towards lifelong learning and information literacy levels to reveal the learning profile of teaching candidates because by detecting the interest, attitude, ability, expectation and tendency of teaching candidates, a healthy needs analysis can be carried out and findings can be used in the development of the related programs.

\subsection{Research Questions}

This study aims to examine the relationship between lifelong learning and information literacy skills of teacher candidates. Within this framework, answers are sought for the questions as follows.

1. What are the levels of lifelong learning of teacher candidates?

2. What are the levels of information literacy of teacher candidates?

3. What kind of relationship is there between teacher candidates' lifelong learning skills and information literacy skills?

\section{Materials and Methods}

\subsection{Participants}

One hundred and twenty seven students from first, second, third and fourth grades of Anadolu University, Department of Physical Education and Sports Teacher Training participated in this study. The data were gathered during 2015-2016 Academic Year. 41.7\% of the students in the study population were female, $58.3 \%$ are male. According to the grade levels, it is observed that students are $1^{\text {st }}$ class of $24.4 \%, 2^{\text {nd }}$ class of $27.6 \%, 3^{\text {rd }}$ class of $25.2 \%$ and $4^{\text {th }}$ class of $22.8 \%$. 


\subsection{Data Collection Tools}

Data were collected by means of "Life Long Learning Scale (LLL)" which was originally developed by Coşkun and Demirel [2] and "Information Literacy Scale" which was developed by Adıgüzel [34].

Lifelong Learning Tendency Scale: Lifelong Learning Tendency Scale is a six-point Likert scale instrument with four subsections motivation ( 6 items), perseverance (6 items), self-regulation ( 6 items) and curiosity (9 items). Students are required to rate themselves between 1 to 6 points for each item ("very suitable $=1$ ", "partly suitable $=2$ ", "very slightly suitable $=3$ ", "very slightly not suitable $=4$ ", "partly is not suitable $=5$ ", "not suitable=6"). The validity and reliability of the original instrument was tested by Coşkun and Demirel. The Cronbach's alpha internal consistency coefficient of the scale containing 27 items and four sub-dimensions was calculated to be .89 . In this study, consequence of repeated analysis of the reliability of the scale is determined ".92", respectively. Since this value is a higher than ".70" standard which is adequate for research, it was concluded that that scale can be used in research as a whole [35].

Information Literacy Scale: Information Literacy Scale is a five-point Likert scale instrument with four subsections "defining information needs" (8 items), "access to information" (11 items), "use of information" (5 items), and "ethical and legal settings in use of information" (5 items). Students are required to rate themselves between 1 to 5 points for each item ("always=5", "often=4", "sometimes=3", "occasionally=2", "never=1"). The validity and reliability of the original instrument was tested by Adıgüzel. The Cronbach's alpha internal consistency coefficient of the scale containing 29 items and four sub-dimensions was calculated to be .93 . In this study, consequence of repeated analysis of the reliability of the scale is determined ".96", respectively. Since this value is a higher than ".70" standard which is adequate for research, it was concluded that that scale can be used in research as a whole [35].

\subsection{Analysis}

First, the distribution of the data was analysed with the SPSS program, and the distribution of kurtosis and skewness were examined. Even though in the literature there are no standard values certain accepted, when the normal skewness and kurtosis values are \pm 2 and \pm 7 intervals, Chou and Bentler [36] and Curan, West and Finch [37] stated they show normal distributions. A normal distribution is a cluster that each of which may be defined by a mean and standard deviation of the distribution. When students' Life Long Learning Scale (LLL) and Information Literacy Scale scores are analyzed in terms of kurtosis and skewness, Chou and Bentler [36] and Curan, West and Finch [37] stated that the kurtosis and skewness of the data showed a normal distribution according to the values they said (see to Table 1). After analysis of the distribution of data, of the tests to be used in order to decide whether the examined homogeneous (Levene $>0.05$ ), it is determined that the data are homogeneous. In the data analysis, "mean, standard deviation and Product-Moment Correlation coefficients" were used. Product-Moment Correlation coefficients were calculated in order to see the relationship between the sub-dimensions of lifelong learning and the sub-dimensions of information literacy.

\section{Results}

The first research question asked "What are the levels of lifelong learning of teacher candidates?". Table 1 below shows the data analysis results in response to this question.

Table 1 shows that the student participants' overall scores varied between 62 and 154, with a mean of 118.89 , which suggests that their overall lifelong learning orientation level was slightly above the average score of the scale (94.5). According to the findings obtained, it can be said that lifelong learning trends of students is at a high level. Considering that the lowest and highest scores on our sub-dimensions of motivation $(\mathrm{M}=32.26)$, perseverance $(\mathrm{M}=27.88)$ and self-regulation $(\mathrm{M}=26.12)$ were 6 and 36 , it can be said that these dimensions are found at a high level (Table 1). This can be evaluated a positive result in terms of lifelong learning. Curiosity which is generally the necessity and willingness to obtain information is the motive power that enhances learning. The lowest and highest scores on the curiosity dimension were 9 and 54, respectively. These scores indicate that curiosity dimension was improved at a medium level $(M=37.82)$, and they can be evaluated a positive result in terms of lifelong learning.

Table 1. The level of the students' LLL

\begin{tabular}{|c|c|c|c|c|c|c|c|}
\hline & $\mathbf{N}$ & Mean & Sd & Skewness & $\begin{array}{c}\text { Skewness } \\
\text { Std. Error }\end{array}$ & Kurtosis & $\begin{array}{c}\text { Kurtosis } \\
\text { Std. Error }\end{array}$ \\
\hline Motivation & 127 & 32.26 & 3.27 & -.700 & .215 & -.681 & .427 \\
\hline Perseverance & 127 & 27.88 & 5.11 & -.789 & .215 & .643 & .427 \\
\hline Self-regulation & 127 & 26.11 & 8.04 & -.500 & .215 & -1.127 & .427 \\
\hline Curiosity & 127 & 37.82 & 11.79 & -.439 & .215 & -1.052 & .427 \\
\hline Life Long Learning Total Score & 127 & 124.07 & 21.21 & -.056 & .215 & -1.137 & .427 \\
\hline
\end{tabular}


The second research question asked "What are the levels of information literacy of teacher candidates?". Table 2 below shows the data analysis results in response to this question.

Table 2 shows that the student participants' overall scores varied between 1 and 5 , with a mean of 4.06, which suggests that their overall information literacy level was slightly above the average score of the scale. According to the findings obtained, it is said that information literacy trends of students is at a high level. When the sub-dimensions of information literacy skills are examined, the average of sub-sub-dimensions varies between 4.14 and 3.99 (Table 2). The literacy behaviour that teacher candidates perform highest is "ethical and legal settings in use of information" followed by "defining information needs", "access to information" and "use of information".

The third research question asked "What kind of relationship is there between teacher candidates' lifelong learning skills and information literacy skills?". Table 3 below shows the data analysis results in response to this question.

When Table 3 is examined, it can be seen that there is significant correlation between teacher candidates' lifelong learning skills and information literacy skills. Positive, moderate and significant correlation can be observed between the motivational dimension of lifelong learning scale and "defining information needs", "access to information", "use of information", and "ethical and legal settings in use of information" dimensions of information literacy scale. Besides, positive, moderate and significant correlation can be observed between the perseverance dimension of lifelong learning scale and "defining information needs", "access to information", "use of information", and "ethical and legal settings in use of information" dimensions of information literacy scale. However, positive, weak and insignificant correlation can be observed between the learning coordination dimension of lifelong learning scale and "defining information needs", "access to information", "use of information", and "ethical and legal settings in use of information" dimensions of information literacy scale. Furthermore, positive, low and insignificant correlation between the curiosity dimension of lifelong learning scale "defining information needs", "access to information", "use of information", and "ethical and legal settings in use of information" dimensions of information literacy scale. Lastly, positive, moderate and significant correlation between the total points of lifelong learning scale and total points of information literacy scale.

Table 2. The level of the students' information literacy.

\begin{tabular}{|c|c|c|c|c|c|c|c|}
\hline & $\mathbf{N}$ & Mean & Sd & Skewness & $\begin{array}{c}\text { Skewness } \\
\text { Std. Error }\end{array}$ & Kurtosis & $\begin{array}{c}\text { Kurtosis } \\
\text { Std. Error }\end{array}$ \\
\hline Defining information needs & 127 & 4.06 & .69 & -.821 & .215 & .733 & .427 \\
\hline Access to information & 127 & 4.06 & .64 & -.866 & .215 & .854 & .427 \\
\hline Use of information & 127 & 3.99 & .75 & -1.016 & .215 & 1.202 & .427 \\
\hline Ethical and legal settings in use of information & 127 & 4.14 & .66 & -.921 & .215 & 1.369 & .427 \\
\hline Information Literacy Total Score & 127 & 4.06 & .62 & -.939 & .215 & 1.395 & .427 \\
\hline
\end{tabular}

Table 3. Correlations between sub-dimensions of lifelong learning and sub-dimensions of information literacy

\begin{tabular}{|c|c|c|c|c|c|c|c|c|c|c|}
\hline & 1 & 2 & 3 & 4 & 5 & 6 & 7 & 8 & 9 & 10 \\
\hline Motivation & 1 & & & & & & & & & \\
\hline Perseverance & $.66^{* *}$ & 1 & & & & & & & & \\
\hline Self-regulation & .16 & .10 & 1 & & & & & & & \\
\hline Curiosity & .17 & .17 & $.73^{* *}$ & 1 & & & & & & \\
\hline Defining information needs & $.51^{* *}$ & $.50^{* *}$ & .10 & .10 & 1 & & & & & \\
\hline Access to information & $.51^{* *}$ & $.57^{* *}$ & .10 & .07 & $.84^{* *}$ & 1 & & & & \\
\hline Use of information & $.54^{* *}$ & $.64^{* *}$ & .08 & .06 & $.78^{* *}$ & $.81^{* *}$ & 1 & & & \\
\hline Ethical and legal settings in use of information & $.47^{* *}$ & $.56^{* *}$ & .14 & .07 & $.77^{* *}$ & $.83^{* *}$ & $.78^{* *}$ & 1 & & \\
\hline Life Long Learning Total Score & $.47^{* *}$ & $.47^{* *}$ & $.83^{* *}$ & $.90^{* *}$ & $.29^{* *}$ & $.29^{* *}$ & $.30^{* *}$ & $.30^{* *}$ & 1 & \\
\hline Information Literacy Total Score & $.54^{* *}$ & $.60^{* *}$ & .12 & .08 & $.93^{* *}$ & $.96^{* *}$ & $.90^{* *}$ & $.90^{* *}$ & $.32^{* *}$ & 1 \\
\hline
\end{tabular}

$* \mathrm{p}<.05 ; * * \mathrm{p}<.01$ 


\section{Discussion and Conclusions}

This study aimed to identify students' tendencies on lifelong learning and information literacy and the relationship between lifelong learning and information literacy in teacher candidates. The results were as follows:

This study showed that students' lifelong learning tendencies were high. Depending on the findings, it is thought that the students are open to lifelong learning and they have the motivation to lifelong learning learn. The higher scores for motivation, perseverance, self-regulation and curiosity can be evaluated as cues of the students' preparedness to assume active roles in becoming lifelong learning learners. Also, the higher scores of all sub-dimensions indicate that their skills of evaluating own level of knowledge, organizing learning, locating and using information of sources may not be as strong. The varying degrees of means in the sub-dimensions and whole scale that emerged in this study have also been noted by other researchers. One of these studies was conducted in 2012 by Chen et al [38]. In Chen et al.'s study, it was discovered that engineering students in their study were more skilled in application of skills and knowledge areas. Another study was carried out in 2013 by Gencel [23]. According to Gencel's study, prospective teachers' perceptions towards their LLL competencies were sufficient. Similarly, in the research of Ozciftci and Cakır [18], it was observed that the teachers' LLL tendencies were high. In Kuzu et al. 's [19] study, it was determined that the teacher-candidates' LLL tendencies scale scores is above the scale mean score. Another study was conducted in 2015 by Ayra and Kösterelioğlu [20] who discovered that the teachers' LLL tendencies scale scores is above the scale mean score. Another research was conducted by Karakuş [24]. When the findings of the study are examined, it is seen that the students' lifelong learning competence point is higher than the scale's point, and according to this, the competency of students' lifelong learning is strong. Another research was conducted by Yavuz Konokman and Yanpar Yelken [25]. In accordance with the findings, the perceptions of instructors' lifelong learning competency can be said to be strong. Another research is conducted by İzci and Koç [21]. At the end of the research, it is concluded that teaching candidates have a strong sensibility on the issue of lifelong learning that is required by information age. According to the findings of the research conducted by Demirel, Sadi and Dağyar [26], it is concluded that the lifelong competency of science, physics, chemistry and biology teachers in all the primary schools, secondary schools and high schools that are found in the city of Karaman is strong according to their own statements. On the contrary, there are researches stating that university students' lifelong learning tendencies are weak. One of these researches was conducted by Diker Coşkun and Demirel [2]. As a result of the study, the average point that the students get from the "Scale of Defining Lifelong Learning Tendencies" is lower than the median of the scale; therefore, according to this conclusion, it is considered that university students' tendency towards lifelong learning is weak. It is a significant finding that teaching candidates' tendency towards lifelong learning is strong and all the sub-dimensions' tendency is strong in terms of teaching as occupation because it is of critical importance that teaching candidates who are always a part of education and teaching are highly motivated towards learning, feel curiosity for learning, and show perseverance in performing their future careers and demonstrating effective teaching skills. The results of our study provides some evidence that the students who participated in the research show tendency towards self-improvement, updating their knowledge, and adapting to the contemporary era, in which the phenomenon of change is constantly processed [39].

Depending on the findings of this research, it is understood that teaching candidates generally have the necessary skills that information literacy requires. The sub-literacy space that teaching candidates have actualized their information literacy skills in the highest level is "ethical and legal settings in use of information"; and this is followed by "defining information needs," access to information", and "use of information". It can be said that, due to the regular ethical and legal inspection, teaching candidates are able to make ethical and legal settings using information and have a high level skill.

In a previous study by Sağlam et al. [40], it is shown that the sub-space in which research assistants' information literacy skills is the highest is "abiding the cultural, ethical, legal and social regulations in using information", and the lowest is "evaluating the accessed information". These findings support the achieved result of our study, which is "The sub-information literacy skills that the teaching candidates have are performed in (ethical and legal settings in use of information) at the highest level. In Adigüzel's [41] research with pre-service teachers, it has been concluded that teacher candidates have very little hardship in organising acquired information, exhibiting results by interpretation and using information in problem solving. In the same research, teacher candidates were proven to evaluate the acquired information accurately and to be cautious in accepting ethical and legal regulations about gaining and using information. Adigüzel's findings support the results of our study. In the study that is conducted by Adigüzel [41], it is determined that the sub-space where the teaching candidates' information literacy is at the highest level is "ethical and legal settings in use of information", and were it is at the lowest level is "access to information". In the study which is conducted by Argon, Öztürk and Kılıçaslan [42], it is observed that the level of skills at the activities on information literacy of teaching candidates studying at the department of primary school teaching is at the level of "I don't have any difficulties".

In the scope of this research, when it has been analyzed whether there is a relationship between lifelong learning and information literacy levels, it has been found that there is a 
significant relationship between lifelong learning and information literacy levels. These findings will enable the teaching candidates to develop a positive attitude towards learning, the increase in their efforts towards lifelong learning, and the emergence of their passion to acquire information literacy skills. It is rather meaningful that the correlation is determined to be positive and moderate. Thereby it is understood that as teachers' candidates' information literacy increases, their approach to life-long learning would increase in parallel. When correlation values between sub-dimensions of lifelong learning and sub-dimensions of information literacy are examined, positive and significant correlation is seen between motivation and perseverance sub-dimensions of lifelong learning scale and "defining information needs", "access to information", "use of information" and "ethical and legal settings in use of information" dimensions of information literacy scale. According to this study result, as long as the motivation and perseverance levels of teaching candidates increase, their levels of defining information needs, access to information, use of information and "ethical and legal settings in use of information" levels will increase. However, positive and insignificant correlation is seen between the learning coordination and curiosity sub-dimensions of lifelong learning and "defining information needs", "access to information", "use of information" and "ethical and legal settings in use of information" dimensions of information literacy scale.

Bruce [43], in a study which he correlates lifelong learning and information literacy, emphasizes that information literacy enables individuals to the opportunity of lifelong learning in the personal and occupational context. In another study which correlates information literacy and lifelong learning [30], there's a statement as follows: "The successful individuals of the future will be the individuals who are able to access information; who can use technology in accessing information; who can solve problems; and who can learn on their own. Information societies need individuals who has are skilled at lifelong learning. Every student/individual who is raised in information age is ought to have the basic skill of learning to learn, that is to access the constantly changing information from various sources, to evaluate and use this information."

As a result, there is a significant relationship between students' information literacy skills and LLL levels. This relationship is positive and at moderate level. Thus, it is understood that when students' information literacy skills increase their attitudes toward LLL will also increase in parallel at moderate level.

The universities should emphasize on educational programs that help develop their students' lifelong learning and information literacy behaviors, at bachelor, master and doctorate levels and this should be another education aim and graduate outcome of universities. Furthermore, universities should organize seminars about lifelong learning and information literacy education for their graduated teacher-candidates, and teachers in order to continue the development in their carrier.

\section{REFERENCES}

[1] C. Polat, H. Odabaş. Bilgi Toplumunda Yaşam Boyu Öğrenmenin Anahtarı: Bilgi Okuryazarlığı, Küreselleşme, Demokratikleşme ve Türkiye Uluslararası Sempozyumu, 27-30 March 2008, Antalya (Turkey).

[2] H. Soran, B. Akkoyunlu, Y. Kavak. Yaşam boyu öğrenme becerileri ve eğiticilerin eğitimi programı: Hacettepe Üniversitesi örneği, H.Ü. Eğitim Fakültesi Dergisi, 30, 201-210, 2006.

[3] Y.D. Coşkun, M. Demirel. Üniversite öğrencilerinin yaşam boyu öğrenme eğilimleri, Hacettepe Ǘniversitesi Eğitim Fakültesi Dergisi, 42, 108-120, 2012.

[4] J. Peter. "Foreword" Lifelong Learning, Concepts and Contexts, USA: Routledge, 2008.

[5] Avrupa Komisyonu A memorandum on lifelong learning. Retrieved June 14, 2016 from web site http://www.bologna-berlin2003.de/pdf/MemorandumEng.pdf, 2000 .

[6] J.C. Dunlap, S. Grabinger. Preparing students for lifelong learning: A review of instructional features and teaching methodologies, Performance Improvement Quarterly, 16(2), 6-25, 2003.

[7] E. Reinsch. The relationship among lifelong learning, emotional intelligence and life satisfaction for adults 55 years of age or older, Unpublished $\mathrm{PhD}$ thesis, University of Illinois, 2007

[8] P. C. Candy. Reaffirming a proud tradition: Universities and lifelong learning, Active Learning in Higher Education, 1, 101-125, 2000.

[9] American Library Association (ALA), The information literacy competency standards for higher education, Retrieved June 14, 2016 from web site

http://www.ala.org/acrl/standards/informationliteracycompete ncy, 2000.

[10] M. V. Henderson, A. J. Scheffler. New literacies, standards and teacher education, Education, 124(2), 390-396, 2003.

[11] Council of Australian University Librarians. Information Literacy Standards, Adelaide: Library Publications, 2001.

[12] V. E. Hancock. Information Literacy for Lifelong Learning, Retrieved June 18, 2016 from web site http://www.libraryinstruction.com/information-literacy.html, 2004.

[13] C. Doyle. Information literacy in an information society: A concept for the information age, Retrieved May 1, 2017 from web site http://www.libraryinstruction.com/information-literacy.html, 1994.

[14] P. S. Breivik. Information Literacy For The Sceptical Library Director, IATUL Conference Queensland University of 
Technology, Brisbane, Queensland, Australia 3rd - 7th July, 2000 .

[15] P. Iannuzzi, C. T. Mangrum 11, S. S. Strichart, Teaching Information Literacy Skills, Boston: Allyn and Bacon, 1999.

[16] B. Akkoyunlu. Bilgi Okuryazarlı̆̆ı ve Yaşam Boyu Öğrenme. 8th International Educational Technology Conference (IETC2008), 6-9 May1s 2008, Anadolu Üniversitesi, Eskişehir.

[17] K. Selvi. Teachers' lifelong learning competencies, Uluslararası Eğitim Programları ve Öğretim Dergisi, 1 (1), 61-69, 2011.

[18] M. Ozciftci, R. Cakır. Öğretmenlerin yaşam boyu öğrenme eğilimleri ve eğitim teknolojisi standartları özyeterliklerinin incelenmesi, Eğitim Teknolojisi Kuram ve Uygulama, 5(1), $1-19,2015$

[19] S. Kuzu, S. Demir, M. Canpolat. Evaluation of life-long learning tendencies of pre-service teachers in terms of some variables, Journal of Theory and Practice in Education, 11(4), 1089-1105, 2015.

[20] M. Ayra, I. Kösterelioğlu. Öğretmenlerin yaşam boyu öğrenme eğilimlerinin mesleki öz yeterlik algıları ile ilişkisi, NWSA-Education Sciences, 10(1), 17-28, 2015.

[21] E. İzci, S. Koç. Öğretmen adaylarının yaşam boyu öğrenmeye ilișkin görüșlerinin belirlenmesi, Adıyaman Üniversitesi Sosyal Bilimler Enstitüsü Dergisi, 5 (9), 101-114, 2012.

[22] N. Köksal, S. Çöğmen. Pre-Service teachers as lifelong learners: University facilities for promoting their professional development, Eurasian Journal of Educational Research, 53, $21-40,2013$

[23] İ. E. Gencel. Öğretmen adaylarının yaşam boyu öğrenme yeterliklerine yönelik algıları, Eğitim ve Bilim, 38 (170), 237-252, 2013.

[24] C. Karakuș. Meslek yüksek okulu öğrencilerinin yaşam boyu öğrenme yeterlikleri, Eğitim ve Öğretim Araştırmaları Dergisi, 2 (3), 26-35, 2013.

[25] G. Yavuz Konokman, T. Yanpar Yelken. The perceptions of academicians in education faculties on their lifelong learning competencies, Hacettepe Üniversitesi Eğitim Fakültesi Dergisi, 29(2), 267-281, 2014.

[26] M. Demirel, Ö. Sadi, M. Dağyar. Fen bilimleri öğretmenlerinin yaşam boyu öğrenme yeterliklerinin incelenmesi (Karaman ili örneği), Pegem Eğitim ve Öğretim Dergisi, 6(1), 19-40, 2016.

[27] B. Akkoyunlu, M. Yılmaz. Öğretmen adaylarının bilgi okuryazarlık düzeyleri ile internet kullanım sıklıkları ve internet kullanım amaçları. Eurasian Journal of Educational Research, 19, 1-14, 2005.

[28] C. Polat. Üniversitelerde bilgi okuryazarlığı programlarının geliştirilmesi: Hacettepe Üniversitesi örneği, Yayımlanmamış doktora tezi, Hacettepe Üniversitesi, Ankara, 2004.
[29] M. Başaran. Sınıf öğretmeni adaylarının bilgi okuryazarlıklarının değerlendirilmesi. G.Ü. Gazi Eðitim Fakültesi Dergisi, 25(3), 163- 177, 2005.

[30] S. Kurbanoğlu, B. Akkoyunlu. Öğrencilere bilgi okuryazarlığ1 becerilerinin kazandırılması, Hacettepe Üniversitesi Eğitim Fakültesi Dergisi, 21, 81-88, 2001.

[31] A. Aldemir. Öğretmen adaylarının bilgi okuryazarlığı düzeyleri üzerine bir araştırma: Sakarya Üniversitesi örneği, Yayımlanmamış Yüksek Lisans tezi, Hacettepe Üniversitesi Sosyal Bilimler Enstitüsü, Ankara, 2004.

[32] M. Ringsted. Open learning in primary and secondary schools-towards the school of tomorrow in the information society. Educational Media International, 35(4), 278-281, 1998.

[33] P. S. Breivik. Take II- Information literacy: Revolution in education, Reference Service Review, 27(3), 271-275, 1999.

[34] A. Adıgüzel. Bilgi okuryazarlığı ölçeğinin geliştirilmesi, Dicle Üniversitesi Ziya Gökalp Eğitim Fakültesi Dergisi, 17, 15-28, 2011.

[35] Ş. Kalaycı. SPSS Uygulamalı Çok Değişkenli İstatistik Teknikleri, Ankara: Asil Yayın Dağıtım, 2008.

[36] C. P. Chou, P. M. Bentler. Estimates and Tests in Structural Equation Modelling. In: RH Hoyle (Eds.): Structural Equation Modelling: Concepts, Issues and Applications, Thousand Oaks, CA: Sage Publications, pp. 37-55, 1995.

[37] P. J. Curan, S. G. West, J. F. Finch. The robustness of test statistics to non-normality and specification error in confirmatory factor analysis, Psychological Methods, 1(1), 16-29, 1996.

[38] J. C. Chen, K. McGaughey, S. M. Lord. Measuring students' propensity for lifelong learning, Paper Presented in 2012 AAEE Conference, Melbourne, Victoria, Australia, December $3-5,2012$

[39] D. Yalız Solmaz, G. Aydın. Evaluation of lifelong learning tendencies of pre-service teachers, Anthropologist, 24(1), $55-63,2016$.

[40] M. Sağlam, A. Adıgüzel, D. Kara, İ. Z. Özonay. Araştırma Görevlilerinin Bilgi Okuryazarlığı Beceri Düzeylerinin Bazı Değişkenler Açısından İncelenmesi, III. Ulusal Lisansüstü Eğitim Sempozyumu, 17-20 Ekim 2007, Eskişehir.

[41] A. Adıgüzel. Öğretmen adaylarının öğrenmeye ilişkin tutumları ile bilgi okuryazarlı becerileri arasındaki ilişkinin çeşitli değişkenler açısından incelenmesi, İJOCİS, 4(7), 13-24, 2014.

[42] T. Argon, Ç. Öztürk, H. Kılıçaslan. Sınıf öğretmenliği ögretmen adaylarının bilgi okur-yazarlığı becerileri üzerine bir durum çalışması, Abant İzzet Baysal Üniversitesi Eğitim Fakültesi Dergisi, 8(2), 13-22, 2008.

[43] C. Bruce. The Seven Faces of Information Literacy, Adelaide: Auslib Press, 1997. 